\title{
Effects of drip and alternate furrow method of irrigation on cotton yield and physical water productivity: A case study from farmers' field of Bhavnagar district of Gujarat, India
}

\section{O. P. Singh*}

Department of Agricultural Economics, Institute of Agricultural Sciences, Banaras Hindu University, Varanasi- 221005 (Uttar Pradesh), India

\section{P. K. Singh}

Department of Agricultural Economics, Institute of Agricultural Sciences, Banaras Hindu University, Varanasi- 221005 (Uttar Pradesh), India

${ }^{*}$ Corresponding author. Email: ompsingh@gmail.com

\section{Article Info}

https://doi.org/10.31018/ jans.v13i2.2696

Received: April 24, 2021

Revised: May 28, 2021

Accepted: May 31, 2021

\section{How to Cite}

Singh, O. P. and Singh, P. K. (2021). Effects of drip and alternate furrow method of irrigation on cotton yield and physical water productivity: A case study from farmers' field of Bhavnagar district of Gujarat, India. Journal of Applied and Natural Science, 13 (2), 677 - 685. https://doi.org/10.31018/jans.v13i2.2696

\begin{abstract}
With the growing irrigation water scarcity, the researchers and policymakers are more concerned to improve the irrigation water use efficiency at farmers' field level. The water-saving technologies provide greater control over water delivery to the crop root zone and reduce the non-beneficial evaporation from the crop field. Water productivity is an important concept for measuring and comparing water use efficiency. The present study tried to estimate the irrigation water use and physical water productivity of cotton under alternate furrow and drip irrigation methods in the Bhavnagar district of Gujarat. Results suggest that crop yield and physical water productivity were higher for cotton irrigated by drip method than alternate furrow method during normal rainfall and drought year. The irrigation water use under the drip method of irrigation was lower as compared to the alternate furrow method. In the case of total water (effective rainfall + irrigation water) use, per hectare crop yield and physical water productivity were higher for the drip method of irrigation than the alternate furrow method of irrigating cotton crop during normal rainfall and drought year. In the case of total water use (effective rainfall + irrigation water), it was lower for drip irrigation than the alternate furrow method of irrigating cotton crop during normal rainfall year and drought year. While estimating total water (effective rainfall + irrigation water) use, it was assumed that there is no return flow of water from the cotton field in the study area under both irrigation methods.
\end{abstract}

Keywords: Crop coefficient, Crop evapotranspiration, Effective rainfall, Physical water productivity, Reference evapotranspiration

\section{INTRODUCTION}

The most important two scarce natural resources for agricultural development and economic advancement for any country are land and water (Shrivastava and Kumar, 2015). With the gradual decline in per capita availability of land and water, augmenting agricultural productivity has become more important factor in meeting the demand of agricultural produce to fast growing population of the country. The availability of irrigation water for crop production needs to be judiciously utilized. Land degradation due to soil salinity and waterlogging is threatening the sustainable use of land resources in India. Globally, salt affected soils increased from 45 million hectare in 1990 to 62 million hectares in 2013 (Qadir et al., 2014). According to Qadir et al. (2014; 2015), salt-induced land degradation has been on the rise and every day, the world is losing about 2000 hectares of land due to salinity.

Cotton is one of the most important fibre-producing plant. India is the second largest producer of cotton in the world after China. In India, the total area under cotton cultivation was 12.43 million hectare and total cotton production in the country was 34.89 million tonnes in 2017-18. The per hectare yield of cotton in the country was $477 \mathrm{~kg}$ during 2017-18. The major cotton producing Indian states are Gujarat, Maharashtra, Telangana, Andhra Pradesh, Rajasthan, Madhya Pradesh, 
Haryana, Punjab and Karnataka. Among the Indian states, Gujarat is the highest cotton producing state. The total area under cotton cultivation in Gujarat was 2.38 million hectares accounting for 22 per cent of India's total area in 2016-17. Total cotton production in Gujarat was 8.58 million tonnes, accounting for 26.32 per cent of the country's total cotton production during 2016-17. Per hectare, the average cotton yield in Gujarat was $612 \mathrm{~kg}$ higher than the national average of cotton yield. The total irrigated area under cotton production in Gujarat was 58.70 per cent during 2014-15. In 2015-16, per hectare cost of cultivation of cotton in Gujarat was estimated to be Rs 55081.77. The average cotton yield in Gujarat was 18.25 quintal per hectare during 2015-16 (Government of India, 2019).

The irrigation water demand management becomes the key to the overall strategy for managing scarce water resources. Since agriculture is the major competitive user of diverted water in India (Singh, 2017; Surendran et al., 2013), demand management in agriculture in water-scarce and water-stressed regions would be central to reducing the aggregate demand for water to match the available future supplies (Singh, 2017; de Fraiture and Wichelns, 2010). With the growing concern about the exploitation of scarce water resources, there is a renewed interest in increasing the water use efficiency in agriculture (Kumar, et al. 2014). One of the important parameter for comparing water use efficiency is water productivity (Kumar, et al. 2014; Hozayn et al., 2013; El-Habbasha et al., 2014).

Three dimensions of water productivity include physical productivity, expressed in kg per unit of water consumed; combined physical and economic productivity expressed in terms of net return per unit of water consumed; and economic productivity expressed in terms of net income returns from a given amount of water consumed against the opportunity cost of using the same amount of water (Kumar et al., 2013). Water productivity is an important driver in projecting future water demands (Kumar et al., 2013). Efficient irrigation technologies help to establish greater control over water delivery (water control) to the crop root zone, reduce non-beneficial evaporation and non-recoverable percolation from the field, and return flows into "sinks" and often increases beneficial ET, though the first component could be very low for field crops (Singh et al., 2013). Water productivity improves with a reduction in depleted fraction and yield enhancement. Since at the theoretical level, water productivity improvements in irrigated agriculture can save water used for crop production, any technological interventions, which improve crop yields, are also, in effect, water saving technologies. Hence, water saving technologies in agriculture can be broadly classified into three: water saving crop technologies, water saving and yield enhancing irrigation technologies; and, yield improving crop technolo- gies (Singh et al., 2013; Kumar and Palanisami, 2011; Palanisami et al., 2011; El-Habbasha et al. 2014; Zafar et al., 2020).

Many past researchers have reported high water use efficiency and crop yield under drip method of irrigation as compared to conventional irrigation throughout the globe (Singh, et al., 2013; Kumar and Palanisami, 2011; Narayanamoorthy, 2012; Abdelraouf et al., 2020; Barkunan et al., 2019; Uddian and Dhar, 2020; Zafar et al., 2020; Mehriya et al., 2020). In drip irrigation, the volume of wetted soil at a particular water application is controlled by the volume of water added, dripper discharge rate and the water content in the soil. Drip method of irrigation is highly suited to semi-arid and arid areas where water is scarce, and low waterconsuming and high-value crops can be grown. In India, drip method of irrigation for cotton crop is being practised by some farmers in Gujarat, Madhya Pradesh and Maharashtra in heavy textured soil viz., black cotton soil. But in light texture and brackish underground water, drip irrigation to cotton crop is at the experimental stage. The overall objective of the present study was to estimate and compare the irrigation water use and physical water productivity of cotton crop under alternate furrow and drip method of irrigation in Bhavnagar district of Gujarat.

\section{MATERIALS AND METHODS}

\section{Methodology}

Present study was based on primary data and it was collected on different parameters for normal rainfall and drought year through personal interview using pretested schedule. These parameters were related to: (a) size of land holding; (b) cotton crop (area under cotton, date of sowing, data of harvesting, plant and row spacing, fertiliser application and crop yield); (c) irrigation (source of irrigation, method of irrigation, number of irrigations and duration per irrigation); (d) well/tube-well (number of wells/tube-wells, depth of well, depth to water level, type of pump, pump capacity and age of pump); and (e) drip (number of drip line per row, spacing between dripper in each line, spacing between laterals, discharge of first dripper on first line, discharge of last dripper on last line and discharge of middle dripper on middle line). The Bhavnagar district of Gujarat was purposively selected for the present study because the district was ranked fourth largest cotton growing district in the Gujarat State. The district consists of nine talukas viz., Ballabhipur, Bhavnagar, Gariyadhar, Ghogha, Mahuva, Palitana, Shihor, Talaja and Umrala (Fig. 1). To represent the district, all the talukas of the district were considered for primary data collection. Sample farmers of these talukas were using groundwater for irrigating the cotton crop. The irrigation methods used by the sample farmers for the cotton crop was a 
drip and alternate furrow. For the present study, 40 farmers were selected for primary data collection. The important criterion for the selection of sampled farmers was

growing cotton and using drip and furrow method of irrigation.

\section{Estimation of irrigation water requirement}

The crop evapotranspiration (ETc), effective rainfall and irrigation water requirement were estimated using CropWat model developed by the Food and Agriculture Organisation (Allen et al., 1998; Bouraima et al., 2015; Amarasinghe et al., 2010; Laghari et al., 2014; Kumari et al., 2017; Kumari et al., 2017a ). In the model, the whole cotton crop period was divided into four stages of crop periods i.e. initial (1-30 days after sowing), development (31-50 days after sowing), mid-season (51-60 days after sowing) and late season (61-95 days after sowing) and crop coefficients were $0.35,0.35,1.20$ and 0.60 respectively. The irrigation water requirements for the crop was estimated by subtracting the effective rainfall from the calculated crop evapotranspiration on a daily basis using the relationship:

$\mathrm{IR}=\mathrm{ET}_{0} \times \mathrm{K}_{\mathrm{c}}-\mathrm{R}_{\mathrm{e}}$

Where,

$I R$ is the net depth of irrigation (mm per day), $E T_{0}$ is reference potential evapotranspiration ( $\mathrm{mm}$ per day), $K_{c}$ is crop coefficient and $R_{e}$ is the effective rainfall.

The Penman-Monteith equation integrated into the CropWat programme (Bouraima et al. 2015) is expressed by equation 2 .

$$
E T_{0}=\frac{0.408 \Delta\left(R_{n}-G\right)+\gamma \frac{37}{T_{h r}+273} u_{2}\left(e^{0}\left(T_{h r}\right)-e_{a}\right.}{\Delta+\gamma^{\left(1+0.34 u_{2}\right)}}
$$

Where:

$E T_{0}=$ reference evapotranspiration $(\mathrm{mm} / \mathrm{hour}$ )

$R_{n}=$ net radiation at the grass surface $\left(\mathrm{MJ} / \mathrm{m}^{2} /\right.$ hour $)$

$G=$ soil heat flux density $\left(\mathrm{MJ} / \mathrm{m}^{2} /\right.$ hour $)$

$\mathbb{A}_{h r}=$ mean hourly air temperature $\left({ }^{\circ} \mathrm{C}\right)$

= saturation slope vapour pressure curve at $\mathrm{T}_{\mathrm{hr}}$ (j $\left.\mathrm{kPa} /{ }^{0} \mathrm{C}\right)$

$=$ psychrometric constant $\left(\mathrm{kPa} /{ }^{0} \mathrm{C}\right)$

$e^{0}\left(T_{h r}\right)=$ saturation vapour pressure at air temperature $\mathrm{T}_{\mathrm{hr}}(\mathrm{kPa})$

$E a=$ average hourly actual vapour pressure $(\mathrm{kPa})$

$U_{2}=$ average hourly wind speed $(\mathrm{m} / \mathrm{s})$

\section{Irrigation water applied}

The estimation of irrigation water applied to cotton crop during crop period was estimated by using the following method (Singh and Singh, 2020):

$\mathrm{IWA}_{(\mathrm{m})}{ }^{3}=\mathrm{NI} \times \mathrm{Hrs} \times \mathrm{Pd}$

Where: IWA is irrigation water applied to cotton $\left(\mathrm{m}^{3} /\right.$ hectare), $\mathrm{NI}$ is number of irrigations given to cotton crop; Hrs is hours required for providing one irrigation to cotton crop (Hrs.) and $P d$ is pump discharge ( $\mathrm{m}^{3} / \mathrm{Hrs}$ ).

The farmers of the study area were using groundwater for irrigating cotton crop. For the quantification of pump discharge rate, following formula was used (Singh, 2017a):

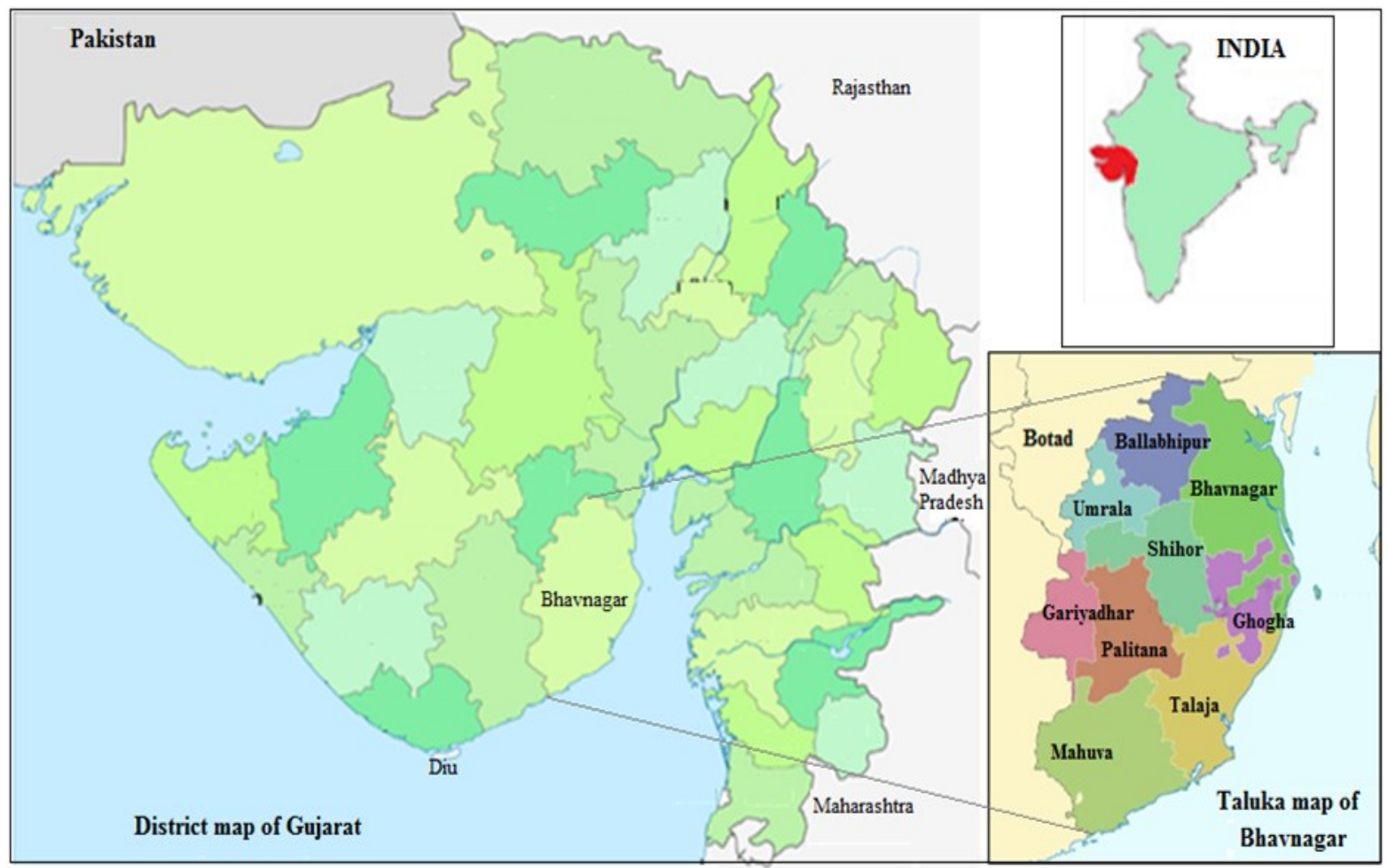

Fig. 1. Location map of Bhavnagar district, Gujarat. 


$$
P d_{\left(m^{3} / H r\right)}=\frac{H P \times 75 \times P e}{1000 \times D W} \times 3600
$$

Where, $P d$ is pump discharge $\left(\mathrm{m}^{3} / \mathrm{Hrs}\right), H P$ is pump capacity measured in horsepower, $P e$ is pump efficiency and $D W$ is depth to water level, including head of delivery (meter).

\section{Applied water physical water productivity}

The applied physical water productivity $\left(\mathrm{kg} / \mathrm{m}^{3}\right)$ for cotton crop grown under alternate furrow and drip irrigated condition was estimated as (Singh, 2017a):

$$
\mathrm{WP}_{\left(\mathrm{kg} / \mathrm{m}^{3}\right)}=\text { Cotton yield }(\mathrm{kg} / \mathrm{ha}) / \Delta
$$

Where,

WP is physical water applied productivity $\left(\mathrm{kg} / \mathrm{m}^{3}\right)$ and $\Delta$ is irrigation water applied $\left(\mathrm{m}^{3}\right)$ per hectare.

\section{Total water used and physical water productivity}

The cotton crop was using lot of the green water (rainfall) during the monsoon season. For estimation of total water used for cotton production viz., both effective rainfall and irrigation water were added. Here it is assumed that there is no return flow from the cotton field under both method of irrigation viz., alternate furrow and drip irrigation. The physical water productivity $\left(\mathrm{kg} / \mathrm{m}^{3}\right)$ for alternate furrow and drip method of irrigation was estimated as:

Where

$$
\mathrm{WP}=\text { Cotton yield } /(\Delta+\mathrm{Pe})
$$

$W P$ is physical water applied productivity $\left(\mathrm{kg} / \mathrm{m}^{3}\right)$, $\Delta$ is total irrigation water applied $\left(\mathrm{m}^{3}\right)$ and $P e$ is effective rainfall.

\section{RESULTS AND DISCUSSION}

\section{Groundwater resources of Bhavnagar district}

As per Central Ground Water Board estimate for the year 2017 , total groundwater recharge during the monsoon (June to September) and non-monsoon (October to May) period was $819.61 \mathrm{MCM}$. Out of total groundwater recharge, 73.98 per cent recharge comes from rainfall, 14.77 per cent recharge from other sources during monsoon season and the remaining 8.20 per cent groundwater recharge was from other sources during the non-monsoon season (Government of India , 2019a). The total natural discharge was $40.98 \mathrm{MCM}$ (Table 1).

The annual extractable groundwater resources were estimated to be $778.63 \mathrm{MCM}$ in 2017. Total annual groundwater extraction in the Bhavnagar district was 463.52 MCM. Out of this, nearly 92.98 per cent of groundwater was being used for irrigated crop produc- tion. The share of groundwater use for industrial and domestic uses were 1.05 and 5.97 per cent, respectively. The stage of groundwater development in the district was 59.53 per cent. All the talukas of the districts were falls under the safe zone.

\section{Land holding size and soil type}

The average size of landholding of the sample farmers in the study area was found to be 1.76 hectares. The average size of landholding for alternate furrow method for cotton irrigated farmers were 1.49 hectare, whereas, in the case of drip irrigated cotton growers, the average size of landholding was 2.06 hectare. The soil available in the study area was heavy textured soil viz. black cotton soil.

\section{Crop evapotranspiration, effective rainfall and irri- gation water requirement}

During the normal rainfall year, the cotton crop duration ranged between 150 days to 250 days (Fig. 2). The crop evapotranspiration $\left(E T_{c}\right)$ for the entire period of the cotton crop was increasing with an increase in crop duration. Crop evapotranspiration was $583.4 \mathrm{~mm}$ for 150 days crop duration and it was increased to the level of $917.4 \mathrm{~mm}$ for 250 days cotton crop. For the short duration of the cotton crop (150 to 212 days), most of the $\mathrm{ET}_{\mathrm{c}}$ requirement was met out from the effective rainfall and after that (222 to 250 days), the share of effective rainfall was showing a declining trend. The gap between $\mathrm{ET}_{\mathrm{c}}$ and effective rainfall was met out by supplying irrigation water to crop.

The irrigation water requirement was also increasing with an increase in crop duration. The effective rainfall ranging between 452.7 to $507.2 \mathrm{~mm}$ and irrigation water requirement ranged between 179.3 to 598.3 $\mathrm{mm}$. The crop duration during the drought year in the study area ranged between 122 days to 252 days (Fig. 3). During the drought year, the ETc for the entire cotton period in the study area ranged between 481.2 to $925.4 \mathrm{~mm}$. During the short duration of the cotton crop (122 to 145 days) most of the $\mathrm{ET}_{\mathrm{c}}$ requirement was met out from the effective rainfall after that (145 to 252 days) larger part of $\mathrm{ET}_{\mathrm{c}}$ requirement was met out from the irrigation water. The effective rainfall ranging between 324.5 to $323.9 \mathrm{~mm}$ and irrigation water requirement ranged between 230.3 to $743.8 \mathrm{~mm}$.

The evapotranspiration demand depends on temperature, solar radiation, humidity, wind speed and plant characteristics like stomatal conductance and leaf area index (Priya et al., 2014). If a region becomes warmer, there will be increased evaporative demand and more irrigation water will be required to maintain crop yields (Priya et al. 2014). In the study area, the evapotranspiration was higher during drought year 
Table 1. Dynamic ground water resources of Bhavnagar District, 2017.

\begin{tabular}{ll}
\hline Particulars & $\begin{array}{l}\text { Million Cubic } \\
\text { Meter (MCM) }\end{array}$ \\
\hline $\begin{array}{l}\text { 1. Total groundwater recharge } \\
\text { (monsoon \& non-monsoon season) }\end{array}$ & 819.61 \\
$\begin{array}{l}\text { 2. Total natural discharge } \\
\text { 3. Annual Extractable Ground }\end{array}$ & 40.98 \\
Water Resources & 778.63 \\
$\begin{array}{l}\text { 4. Current annual groundwater } \\
\text { extraction: }\end{array}$ & 463.52 \\
$\begin{array}{l}\text { a. Irrigation } \\
\text { b. Industrial }\end{array}$ & 430.98 \\
c. Domestic & 4.88 \\
$\begin{array}{l}\text { 5. Net Ground Water Availability } \\
\text { for future use }\end{array}$ & 27.66 \\
6. Stage of Ground Water & 296.18 \\
Extraction (\%) & 59.53 \\
\hline
\end{tabular}

Government of India , 2019a

as compared to normal rainfall year. As a result, irrigation water requirement was more and effective rainfall was less during drought year as compared to normal rainfall year.

\section{Fertilizer application}

Fig. 4 represents the fertilizer applied by the sample farmers in the cotton crop during normal rainfall and drought year. During the normal rainfall, the average quantity of chemical fertilizer applied by the sample farmers in the study area was $329 \mathrm{~kg}$ per hectare and it was ranging between 137 to 561 per hectares. During a

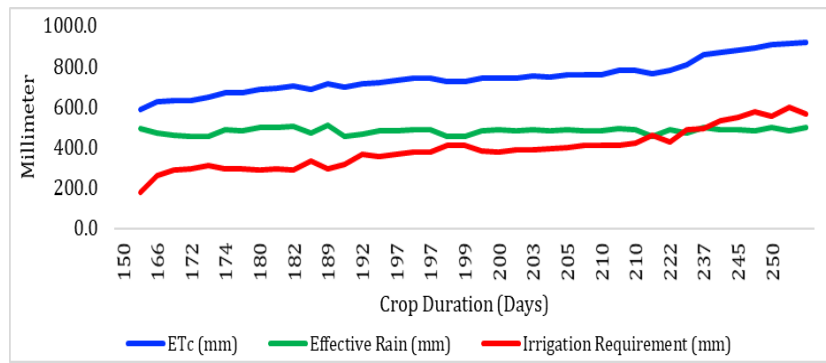

Fig. 2. ETc, effective rainfall and irrigation requirement during normal rainfall year.

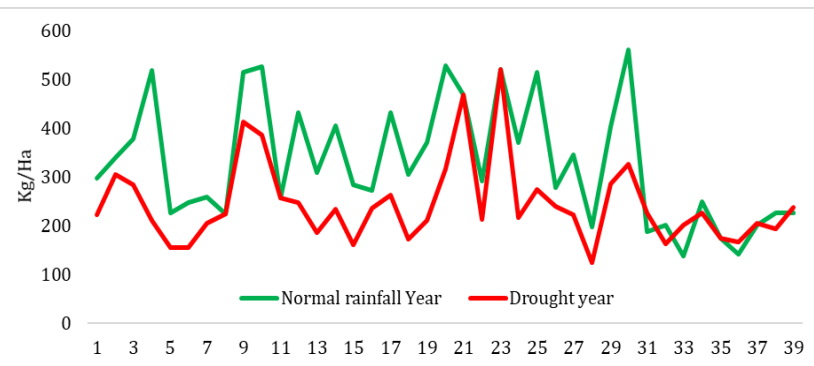

Fig. 4. Fertilizer application in cotton during normal rainfall and drought year. drought year, the average quantity of fertilizer applied by the sample farmers was $244 \mathrm{~kg}$ per hectare and it was ranging between 124 to $521 \mathrm{~kg}$ per hectare. It is clear from the above discussion that during the drought year, fertilizer application to the cotton crop was reduced by 25.82 per cent as compared to normal rainfall year. Past researchers reported that there is positive and significant relationship between irrigation water use and intensity of fertilizer application (Yan et al., 2019; Zafar et. al., 2020; Feng et al., 2020; Lian et al., 2017). Similar results were also observed in the study area. The doses of fertilizer application in cotton crop was higher during the normal rainfall year as compared to drought year in the study area.

\section{Crop yield}

Agricultural production largely depends upon natural calamities. Despite the fact that Indian government and farmers were creating/developing irrigation facility for providing irrigation water to the crop. Fig. 5 represents the cotton yield during normal rainfall and drought year for the sample farmers. During the normal rainfall year, the average per hectare cotton yield for sample farmers was estimated to be $2386 \mathrm{~kg}$ and it was ranging between 1333 to $3875 \mathrm{~kg}$. During the drought year, the average cotton yield in the study area was estimated to be $1499 \mathrm{~kg}$ per hectare. The cotton yield of the sample farmers during drought year was ranging between 172 to $2500 \mathrm{~kg}$ per hectare. The cotton yield during drought year was nearly 37.18 per cent, which was lower than the normal rainfall year.

The past researchers reported that there is a linear relationship between crop yield and irrigation water

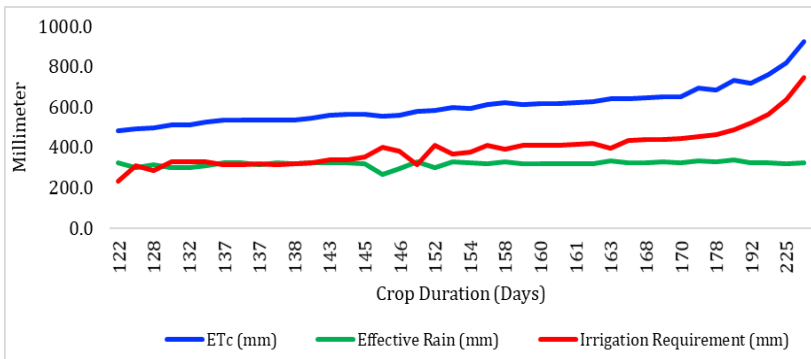

Fig. 3. ETC, effective rainfall and irrigation requirement during drought year.

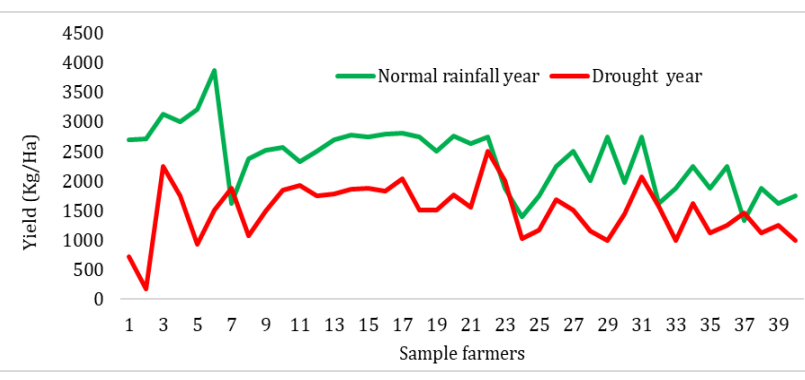

Fig. 5. Cotton yield during normal rainfall and drought year. 
supply less than optimum (deficit) irrigation ( $\mathrm{Li}$ et al., 2017; Montoya et al., 2017; Fucang et al., 2015; Zafar et al., 2020). Massive output return of agricultural production can be achieved by maintaining environmental quality and efficiently managing inputs practising like irrigation scheduling and efficient use of fertilizer (Macintosh et al., 2019; Willy et al., 2019). Similar results were also observed in the study area. During normal rainfall year, the cotton yield was higher than the drought year.

\section{Irrigation water use and water productivity}

Table 2 represents the cotton yield, irrigation water applied for growing irrigated cotton and physical irrigation water productivity of sample farmers during normal rainfall and drought year under alternate furrow and drip method of irrigation. It is clear that during the normal year, farmers were getting higher cotton yield as compared to drought year under both methods of irrigation viz., alternate furrow and drip. During the normal rainfall year, farmers were applying less irrigation water under both irrigation methods compared to drought year. The physical water productivity for applied water was higher for both the irrigation method during normal rainfall year compared to drought year. The crop yield and physical water productivity for the drip irrigation method were higher during normal rainfall year and drought year than the alternate furrow irrigation method. The sample farmers applied less volume of irrigation water under drip method of irrigation compared to alternate furrow method of irrigation during normal rainfall and drought year.

During the normal rainfall year, the per hectare cotton yield of the sample farmers in the study area was found to be 2313 and $3389 \mathrm{~kg}$ for alternate furrow and drip irrigation method, respectively (Table 2). The average volume of irrigation water applied for cotton production under alternate furrow and drip irrigation method was estimated to be 4486.09 and $2994.97 \mathrm{~m}^{3}$ per hectare. The applied physical water productivity was highest for the drip irrigation method $\left(0.97 \mathrm{~kg} / \mathrm{m}^{3}\right)$ compared to the alternate furrow method of irrigation $\left(0.79 \mathrm{~kg} / \mathrm{m}^{3}\right)$.

During the drought year, per hectare average cotton yield in the study area was estimated to be 1593 and $1985 \mathrm{~kg}$ under alternate furrow and drip irrigation, respectively (Table 2). The irrigation water applied by the sample farmers for irrigated cotton production under alternate furrow and drip method of irrigation was found to be 6521.82 and $5086.44 \mathrm{~m}^{3}$ per hectare, respectively. The applied physical water productivity was found to be 0.33 and $0.40 \mathrm{~kg}$ per $\mathrm{m}^{3}$ for alternate furrow and drip method of irrigation, respectively. Many past researchers reported that after the adoption of water saving technology, i.e. Drip, crop yield under drip method of irrigation was higher than conventional/alternate furrow method of irrigation (Fucang et al., 2015; Parthasarathi et al., 2018; Assefa et al., 2019; Abdelraouf et al. 2020; Barkunan et al., 2019; Uddian and Dhar, 2020; Mehriya et al., 2020)

\section{Total water use and water productivity}

Per hectare cotton yield, total water use (effective rainfall + irrigation water) and physical water productivity for cotton crop under alternate furrow and drip irrigation methods are presented in Table 3. Here, it is assumed that there is no return flow from the cotton field in the study area under both irrigation methods, i.e. alternate furrow and drip irrigation. It is clear from Table 3 that the per hectare cotton yield, total water use and physical water productivity was higher under drip irrigation for both conditions viz., normal rainfall year and drought year as compared to alternate furrow method of irrigation.

During the normal rainfall year, the sample farmers' per hectare average cotton yield was 2313 and $3389 \mathrm{~kg}$ for alternate furrow and drip method of irrigation, respectively. Total water (effective rainfall + irrigation water) used for cotton production in the study area was 7931.37 and $5612.21 \mathrm{~m}^{3}$ per hectare under alternate furrow and drip irrigation. The physical water productivity was found to be 0.29 and $0.60 \mathrm{~kg}$ per $\mathrm{m}^{3}$ for alternate furrow and drip method of irrigation, respectively (Table 3).

During the drought year, per hectare, the average cotton production in the study area was estimated to be 1577 and $1638 \mathrm{~kg}$ under alternate furrow and drip irri-

Table 2. Cotton yield, irrigation water use and physical water productivity.

\begin{tabular}{|c|c|c|}
\hline \multirow{2}{*}{ Particulars } & \multicolumn{2}{|c|}{ Method of Irrigation } \\
\hline & Alternate furrow & Drip \\
\hline \multicolumn{3}{|c|}{ Normal Rainfall Year } \\
\hline Crop Yield $(\mathrm{Kg} / \mathrm{Ha})$ & 2313 & 3389 \\
\hline Irrigation water applied $\left(\mathrm{m}^{3} / \mathrm{Ha}\right)$ & 4486.09 & 2994.97 \\
\hline Physical irrigation water productivity $\left(\mathrm{Kg} / \mathrm{m}^{3}\right)$ & 0.79 & 0.97 \\
\hline \multicolumn{3}{|c|}{ Drought Year } \\
\hline Crop Yield (Kg/Ha) & 1593 & 1985 \\
\hline Irrigation water applied $\left(\mathrm{m}^{3} / \mathrm{Ha}\right)$ & 6521.82 & 5086.44 \\
\hline Physical irrigation water productivity $\left(\mathrm{Kg} / \mathrm{m}^{3}\right)$ & 0.33 & 0.40 \\
\hline
\end{tabular}


Singh, O. P. and Singh, P. K. / J. Appl. \& Nat. Sci. 13(2), 677 - 685 (2021)

Table 3. Cotton yield, total water use and physical water productivity.

\begin{tabular}{|c|c|c|}
\hline \multirow{2}{*}{ Particulars } & \multicolumn{2}{|c|}{ Method of Irrigation } \\
\hline & Alternate furrow & Drip \\
\hline \multicolumn{3}{|c|}{ Normal Rainfall Year } \\
\hline Crop yield $(\mathrm{Kg} / \mathrm{Ha})$ & 2313 & 3389 \\
\hline Total water used [effective rainfall + irrigation water] $\left(\mathrm{m}^{3} / \mathrm{Ha}\right)$ & 7931.37 & 5612.21 \\
\hline Physical water productivity $\left(\mathrm{Kg} / \mathrm{m}^{3}\right)$ & 0.29 & 0.60 \\
\hline \multicolumn{3}{|c|}{ Drought Year } \\
\hline Crop yield $(\mathrm{Kg} / \mathrm{Ha})$ & 1577 & 1638 \\
\hline Total water used [effective rainfall + irrigation water] $\left(\mathrm{m}^{3} / \mathrm{Ha}\right)$ & 6006.22 & 5163.04 \\
\hline Physical water productivity $\left(\mathrm{Kg} / \mathrm{m}^{3}\right)$ & 0.26 & 0.32 \\
\hline
\end{tabular}

gated cotton production, respectively. The total water (effective rainfall + irrigation water) used by the sample farmers for irrigated cotton production for alternate furrow and drip irrigation method was estimated to be 6006.22 and $5163.04 \mathrm{~m}^{3}$ per hectare, respectively. The physical water productivity for the cotton crop grown under alternate furrow and drip method of irrigation was 0.26 and $0.32 \mathrm{~kg}$ per $\mathrm{m}^{3}$, respectively (Table 3).

\section{Conclusion}

With the adoption of the drip irrigation method, water could be directly applied to the plants' root zone, which prevents the non-beneficial evaporation loss. In 2017, out of total groundwater use in the Bhavnagar district, nearly 93 per cent of groundwater was used for irrigated crop production. During the normal rainfall year, cotton crop duration ranged between 150 to 250 days, whereas, in the case of a drought year, it ranged between 122 to 252 days. The physical water productivity for applied water was estimated to be 0.79 and $0.97 \mathrm{~kg}$ per $\mathrm{m}^{3}$ for alternate furrow and drip method of irrigation during normal rainfall year. During the drought year, physical water productivity for applied water for alternate furrow and drip method of irrigation was found to be 0.33 and $0.40 \mathrm{~kg}$ per $\mathrm{m}^{3}$ respectively. The physical water productivity for total water use (effective rainfall + irrigation water) was found to be 0.29 and $0.60 \mathrm{~kg}$ per $\mathrm{m}^{3}$ under alternate furrow and drip irrigation methods, respectively, during normal rainfall. During a drought year, physical water productivity for total water (effective rainfall + irrigation water) was estimated to be 0.26 and 0.32 $\mathrm{kg}$ per $\mathrm{m}^{3}$ for alternate furrow and drip method of cotton irrigation. Therefore, researchers, policymakers and government should frame a policy to motivate farmers to adopt suitable water saving technologies for suitable crops in water-scarce regions of the country. This will save the precious irrigation water and augment the crop yield and, ultimately economic prosperity of the farming community.

\section{Conflict of interest}

The authors declare that they have no conflict of interest.

\section{REFERENCES}

1. Abdelraouf, R. E., El-Shawadfy, M. A., Ghoname, A. A. \& Ragab, R. (2020). Improving crop production and water productivity using new field drip irrigation design, Plant Archives, 20 (Supplement 1), 3553-3564.

2. Allen, R. G., Pereira, L. S., Raes, D. \& Smith Martin (1998). Crop Evapotranspiration-guidelines for computing crop water requirement, $F A O$ Irrigation and Drainage $\mathrm{Pa}$ per No. 56, Food and Agriculture Organisation, Rome, Italy.

3. Amarasinghe, U. A., Smakhtin, V., Sharma, B. R. \& Eriyagama, N. (2010). Bailout with white revolution or sink deeper? Groundwater depletion and impacts in the Moga district of Punjab, India, IWMI Research Report 138, Colombo, International Water Management Institute, Colombo, Sri Lanka.

4. Assefa, T., Jha, Manoj, Reyes, Manuel, Tilahun, Seifu \& Worqlul, A. W. (2019). Experimental evaluation of conservation agriculture with drip irrigation for water productivity in Sub-Saharan Africa, Water, 11 (3),530-543. DOI: https://doi.org/10.3390/w11030530

5. Barkunan, S. R., Bhanumathi, V. \& Sethuram, J. (2019). Smart sensor for automatic drip irrigation system for paddy cultivation, Computer Electronic Engineering, 73, 180193. DOI: https://doi.org/10.1016/j.compeleceng.201 8.11.013

6. Bouraima, K. A., Zhang, W. \& Wei, C. (2015). Irrigation water requirements of rice using CropWat model in Northern Benin, International Journal of Agricultural and Biological Engineering, 8 (2), 58 - 64. DOI: 10.3965/j.jjabe.20 150802.1290

7. De Fraiture, C. \& Wichelns, D. (2010). Satisfying future water demands for agriculture, Agricultural Water Management, 97, 502-511. https://doi.org/10.1016/ j.agwat.2009.08.008

8. El-Habbasha, S. F., Okasha, E. M., Abdelraouf, R. E. \& Mohammed, A. S. H. (2014). Effect of pressured irrigation systems, deficit irrigation and fertigation rates on yield, quality and water use efficiency of groundnut, International Journal of Chemical Technology Research, 7(1), 22-32.

9. Feng, J., Hussain, H. A., Hussain, S., Shi, C, Cholidah, L., Men, S., Ke, J., \& Wang, L. (2020). Optimum water and 
fertiliser management for better growth and resource use efficiency of rapeseed in rainy and drought season, Sustainability, 12, 703. DOI: 10.3390/su12020703

10. Fucang, Z., Ligeng, W., Junliang, F., Yan, Z., Jing, Li \& Yingying, $X$. (2015). Determination of optimal amount of irrigation and fertiliser under, drip fertigated system based on tomato yield, quality, water and, fertiliser use efficiency, Transactions of the Chinese Society of Agricultural Engineering, 31 (Supplement), 110-121.

11. Government of India (2019). Agricultural statistics at a glance 2018. Directorate of Economics and Statistics, Department of Agriculture, Cooperation and Farmers Welfare, Ministry of Agriculture and Farmers Welfare, Government of India, New Delhi.

12. Government of India (2019a). National compilation on Dynamic ground water resources of India, 2017. Central Groundwater Board, Department of water resources RD \& GR, Ministry of Jal Shakti, Government of India, Faridabad.

13. Hozayn, M. El-Monem, A. A. Abd, Abdelraouf, R. E. \& Abdalla, M. M. (2013). Do Magnetic water affect water use efficiency, quality and yield of sugar beet (Beta vulgari L.) plant under arid regions conditions? Journal of Agronomy, 12(1), 1-10. DOI: 10.3923/ja.2013.1.10

14. Kumar, D. Suresh \& Palanisami, K. (2011). Can drip irrigation technology be socially beneficial? Evidence from southern India, Water Policy, 13(4), 571 - 587. https:// doi.org/10.2166/WP.2010.311

15. Kumar, M. Dinesh, Christopher A. Scott \& Singh, O. P. (2013). Can India raise agricultural productivity while reducing groundwater and energy use? International Journal of Water Resource Development, 20(4), 557-573. DOI: 10.1080/07900627.2012.743957

16. Kumar, M. Dinesh, Christopher A. Scott \& Singh, O. P. (2014). Raising agricultural productivity with reduced use of energy and groundwater: Role of market instrument and technology. In Kumar, M. Dinesh, Bassi, Nitin, Narayanmoorthy, A. \& MVK Sivmohan (eds.) The water, energy and food security nexus: lesson from India for development. Rouldge and Routledge, Abindgon, OX 14 4RN and New York NY007, 97-124.

17. Kumari, Maina, Singh, O. P. \& Meena, Dinesh Chand (2017). Optimising cropping pattern in Eastern Uttar Pradesh using Sen's multi objective programming approach, Agricultural Economics Research Review, 30(2), 285 291. DOI: $10.5958 / 0974-0279.2017 .00049 .0$

18. Kumari, Maina, Singh, O. P. \& Meena, Dinesh Chand (2017). Crop water requirement, water productivity and comparative advantage of crop production in different regions of Uttar Pradesh, India, International Journal of Current Microbiology and Applied Sciences, 6(7), 20432052. DOI: https://doi.org/10.20546/ijcmas.2017.60 7.242

19. Laghari, T. S., Khaliq, A., Shah, S. H. H., Ali, S. Shahzad, H. \& Nasir, U. (2014). Analysis of rainfall data to estimate rain contribution towards crop water requirement using CropWat model, Russian Journal of Agricultural and Socio -Economic Sciences, 12(36, 9-17

20. Li, Maona, Liu, Yang, Yan, Haijun \& Sui, Ruixiu (2017). Effects of irrigation amount on alfalfa yield and quality with a center-pivot system, Transactions of the ASABE, 60(5): 1633-1644. DOI: 10.13031/trans.12239

21. Lian, Yanhao, Meng, Xiangping, Yang, Zhen, Wang,
Tianlu, Ali, Shahzad, Yang, Baoping, Zhang, Peng, Han, Qingfang, Jia, Zhikuan \& Ren, Xiaolong (2017). Strategies for reducing the fertilizer application rate in the ridge and furrow rainfall harvesting system in semiarid regions, Scientific Reports-2644, 1-15. DOI:10.1035/s41598-01702731-ywww.nature.com/articles/s41598-017-02731-y.p df

22. Macintosh, K. A., Doody, D. G., Withers, P. J., McDowell, R. W. Smith, D. R., Johnson, L. T., Bruulsema, T. W., O'Flaherty, V., \& McGrath, J. W. (2019). Transforming soil phosphorus fertility management strategies to support the delivery of multiple ecosystem services from agricultural systems, Science Total Environment, 649: 90-98. DOI: https://doi.org/10.1016/j.scitotenv.2018.08.272

23. Mehriya, M. L., Geat, Neelam, Sarita, Singh, H., Mattar, M. A. \& Elansary, H. O. (2020). Response of drip irrigation and fertigation on cumin yield, quality, and water use efficiency grown under arid climatic condition, Agronomy, 10, 1711. DOI: 10.3390 /agronomy 10111711

24. Montoya, F. Garcia, C. Pintos, F. \& Otero, A. (2017). Effects of irrigation regime on the growth and yield of irrigated soybean in temperate humid climatic conditions, Agricultural Water Management, 193, 30-45. DOI. https:// doi.org/10.1016/j.agwat.2017.08.001

25. Narayanmurthy, A. (2012). Drip method of irrigation in Maharashtra: Status, economics and outreach. In K. Palanisami, S. Raman \& Mohan K. (eds) Micro irrigation: economics and outreach, Macmillan Publishers India Ltd., Delhi: 120-139

26. Palanisami, K., Mohan, Kadiri, Kakumanu, K. R. \& Raman, S. (2011). Spread and economics of micro-irrigation in India: Evidence from nine States, Economic and Political Weekly, Supplement (Review of Agriculture), 46 (26 \& 27), $81-86$.

27. Parthasarathi, T., Koothan, V., Sendass, M. \& Eli V. (2018). Evaluation of drip irrigation system for water productivity and yield of rice, Agronomy Journal, 110(6), 2378-2389. DOI: https://doi.org/10.2134/agronj2018.0 1.2002

28. Priya, A., Nema, A. K. \& Islam, A. (2014). Effects of climate change and elevated $\mathrm{CO}_{2}$ on reference evapotranspiration in Varanasi, India - a case study, Journal of agrometeorology, 16(1), 44-51.

29. Qadir, M., Noble, A. D., Karajesh, F. \& George, B. (2015). Potential business opportunities from saline water and salt -affected land resources, Resource Recovery and Reuse Series 5. International Water Management Institute, Colombo, Sri Lanka.

30. Qadir, M., Quillerou, E., Nangia, V., Murtaza, G., Singh, M., Thomas, R. J., Drechsel, P. \& Noble, A. (2014). Economics of salt induced land degradation and restoration, Natural Resource Forum, 38(4), 282-295.

31. Shrivastava, Pooj \& Rajesh Kumar (2015). Soil salinity: A serious environmental issue and plant growth promoting bacteria as one of the tools for its alleviation, Saudi Journal of Biological Sciences, 22(2), 123-131. doi: 10.1016/ j.sjbs.2014.122.001

32. Singh, O. P., Singh, P. K., Singh, Rakesh, Badal, P. S. \& Singh, H. P. (2013). Impact of water saving technology on blue water use and productivity: Analysis from North Gujarat, India, International Journal of Agriculture, Environment and Biotechnology, 6(4), 675-684. DOI: 10.5958/j.2230732X.6.4.048 
33. Singh, O. P. (2017). Improving irrigation water productivity in agriculture, Productivity, 57 (4), $362-367$.

34. Singh, O. P. (2017a). Sustainable groundwater management and enhancing wheat yield through resource conservation technologies: Empirical evidences from different agro-climatic zones of Uttar Pradesh, India, Indian Journal of Agricultural Statistical Sciences, 13(1), 67-73.

35. Singh, O. P. \& Singh P. K. (2020). Environmental and socio-economic impact of zero-tillage in Indo-Gangatic plain of Uttar Pradesh, India, Indian Journal of Agricultural Statistical Sciences, 16(2), 589-598.

36. Surendran, U., Sandeep, O., Mammen, G. \& Joseph, E. J. (2013). A novel technique of magnetic treatment of saline and hard water for irrigation and its impact on cow pea growth and water properties, International Journal of Agriculture, Environment and Biotechnology, 6(1), 85-92.

37. Uddian, M. T. \& Dhar, A. R. (2020). Assessing the impact of water-saving technologies on Boro rice farming in Bangladesh: Economic and environmental prospective,
Irrigation Science, 38(1\&2), 199-212. DOI: 10.1007/ s00271-019-00662-2

38. Willy, D. K., Muyanga, M. \& Jayne, T. (2019). Can economic and environmental benefits associated with agricultural intensification be sustained at high population density? A farm level empirical analysis, Land Use Policy, 81, 100-110. DOI: 10.1016/j.landusepol.2018.10.046

39. Yan, S., Wu, Y, Fan, J., Zhang, F., Qiang, S., Zheng, J., Xiang, Y., Guo, J. \& Zou, H. (2019). Effects of water and fertiliser management on grain filling characteristics, grain weight and productivity of drip-fertigated winter wheat, Agricultural Water Management, 213, 983-995. DOI: 10.1016/j.agwat.2018.12.019

40. Zafar, Usman, Muhammad, A., Cheema, M. J. M. \& Amhad, R. (2020), Sensor based drip irrigation to enhance crop yield and water productivity in Semi-arid climatic region of Pakistan, Pakistan Journal of Agricultural Sciences, 57(5), 1293-1301. DOI: 10.21162/PAKJAS/20.83 